\title{
Poetic Examination of Spatial Experience: Suprematist Composition No. 1, Black on Grey by Kristina Leko
}

Keywords: alternative space, interactive art, relational form, suprematism on square

DOI: 10.4312 /ars.12.1.163-176

\section{Introduction ${ }^{1}$}

The article analyses the concept of space in contemporary art based on the example of Suprematist Composition No. 1, Black on Grey by the artist Kristina Leko, created within the series of interventions in public space named "Operation: City 2008”. In reference to Malevich's suprematism, in December 2008 Leko intended to perform an artistic intervention in the main Zagreb square by covering in black all the commercials, advertisements, signs and names of the companies in it. This poetic intervention, as the artist termed it, was aimed at prompting people to question primarily material but also other values in this month in which spiritual qualities are traditionally valued. However, despite the permissions obtained from the city authorities, the project was not realised because the companies concerned refused to remove their respective advertisements. The non-feasibility of the intervention nevertheless raises some completely new questions and is a direct testimony of the ordering of the powers in the public sphere, thereby challenging the paradigm of public spaces as common spheres. Although it has not been realised in its physical form, the work Suprematist Composition No. 1, Black on Grey exists in the virtual or media space, which is also public, and continues to act in the form of documentation. Consequently, it can be viewed as an artistic strategy which, paradoxically, "makes things visible" (Boris Groys). In this work, the artist treats space as having the potential for a qualitative change "both in individual perceptions (individual level) and in the social environment (as a sum of individuals, i.e. intersubjective level)" (Leko, 2008, 238). The space is thus the main carrier of meaning and its poetry is conveyed through the relationships between the visible and invisible, physical and metaphysical, real and

1 The work is an extended version of the text presented at the symposium "Man in Space" as part of the annual conference of the Croatian Philosophical Society in December 2016, Zagreb. 
virtual, aesthetics and ethics, art and politics. The paper will analyse the role of space in the reception of this work, referring to Bourriaud's term of "alternative space" as a kind of alternative market space or a form of resistance to the dominant discourse of marketing propaganda, the roles of which it assumes and reverses.

\section{Suprematism on the square}

Starting from the title Suprematist Composition No. 1, Black on Grey, the artist announces the topic of space, considered either as a composition in terms of an arrangement and the relationship of parts within a whole, or as suprematism as a kind of metaphysics of space in painting. Malevich was one of the first artists to discover the expressive power of empty spaces and pure mathematical forms. Their expressive power creates a new reality and content of an image, which is the absolute domination or supremacy of emotion in the visual arts. As is well-known, Malevich created works that are completely free of any allusions and connotations of the subject, which are in no way inspired by the physical space or the visible appearance of the world, and are not the result of abstraction, but are rather the proposition of a new reality. "The Suprematism Manifesto" explains this notion: the means of painting - colour and form - should have supremacy, that is, be superordinate to the mere representation of the visible, material world. The cosmic transcendence of Malevich's paintings thus incites contemplation of the timeless and the extraspatial: "A black square on a white background was the first form of expression of non-material sensibility: square = sensitivity, white background = 'nothing', what is beyond sensitivity" (Malevich, 1990, 252). Malevich's painting is dynamic, induced, moving toward infinity, the area of "non-material" perfection, and suggests "a direct experience of the absolute and universal, because in abstract, i.e. universal, relations it reveals the true reality of the world, its inner structure. (Briski-Uzelac, 2008, 219) Triangles, rectangles, crosses and trapezoids all stretch and hover in front of infinite spaces, free from the boundaries of the media: "The artist, the painter, is no longer tied to the canvas, to the surface of the painting, but is able to transfer its composition from the canvas into the space" (De Micheli, 1990, 259). Kristina Leko seems to adapt such a concept literally by transferring the suprematist composition into the public physical space of the square, which in turn triggers completely new connotations:

In principle, this artwork can exist in several chromatic variants: black on grey, black and red on grey, and multicoloured, colourful on grey. A work that is dear to my heart is the Black-on-Grey composition, as it has the greatest communicational potential. The composition carries the connotations of censorship, violent elimination, death and darkness, which, in relation to the company advertisements and signs, or signs of 
economic progress, can be read by the average random passer-by without major misunderstandings. Describing what they have seen, they will unmistakably say: Somebody has covered the company advertisements with a black cloth. (Leko, 2008, 238)

The original idea of the Suprematist Composition No. 1, Black on Grey was to remove for one day all the commercials on Jelačić Square, but eventually it was decided to make a test intervention on its eastern side within the Operation City project. As Kristina Leko often makes use of social interaction and participation in her work, this project was planned to be carried out in a similar way, namely, by going to meetings in each company and attempting to explain what this covering of their advertisements by black cloth was intended to convey. The idea was to compile documentation, and thus explore the extent to which ordinary businessmen are willing to concede their advertising space for poetic action. According to the artist, in some companies, such as VIP, City Pharmacies and Konzum, the reactions were favourable, but the project was opposed by some bigger companies - Zagrebačka Banka, Pliva and Erstebank. The latter did not even want to discuss it before they were shown approvals by the City Office for Communal Affairs and Physical Planning, and indeed, not even after that.

When we, together with other projects of the Local Basis for Culture Refreshment /BLOK/, received a recommendation from the City Office for Culture and the consent of the Office for Communal Affairs and Physical Planning, one of the directors of Zagreb Bank called the Mayor's Office and the City Office for Culture, which we came to know accidentally from a person working in the office, it was suddenly decided that this consent should be withdrawn. Therefore, the officials at Zagrebačka Banka were not brave enough to say, "No, we won't do it", because in this case we would have covered other advertisements and theirs would remain standing out. Moreover, this bank's manager knows all too well that this is public space and consequently not really their property and should therefore rightfully be conceded; that's indeed why he intervened - this is a typical demonstration of power. (...) By having its approval withdrawn, this project actually launched an avalanche of new issues. While in the case of the contrary it would have merely been a criticism of consumerism and affirmation of spiritual values, now it gave raise to questions such as how public space is used, who decides about it, why a director of a bank can call a mayor and I cannot, ... And why, indeed, should advertising in public space take precedence over an artistic intervention? Culture is a legitimate social sphere and there must be some space for it. ${ }^{2}$

2 Interview with Kristina Leko; see www.slobodnadalmacija.hr/scena/kultura/clanak/id/32029/ korporacije-protiv-umjetnicke-akcije [1. 2. 2017]. 
By appropriating and setting suprematist metaphysics of the supratemporal and extraspatial into the real dimension of the main city square and the pre-Christmas festive atmosphere of December, the artist articulates two different spatial experiences. The meditative character of Malevich's paintings is clearly contrasted with the market character of the urban landscape and colourful advertising, and in an effective and aesthetically striking way reveals the public space as one of seduction by images and establishment of control, which, paradoxically, the non-realisation of the whole project only confirms. Namely, there is no material form of Leko's work - her work is impossible to experience in the physical space of the square as it is conceived. However, it seems that is precisely through such exclusion that the work entirely justifies and achieves its aim as a suprematist composition. On the one hand, suprematism is one of the last retreats of great narratives about the "autonomy of art"; Malevich himself thinks that art must be useless and should never meet a particular need. Such art is freed from serving the state or religion, illustrating history, which can exist without things (Maljevič, 1990, 252-259). It was already Kant who, with his aesthetic attitude towards disinterested liking, implied the distance and detachment of art from everyday necessities and practical dimensions of life, which Clement Greenberg would later use to elaborate a theory of modernist painting based on media autonomy and the morphological specificity of a picture defined through clear artistic aesthetic effect. However, despite the exclusivity and exclusion of such art from the real world, it is reputed to be of a dangerous and subversive character. It should be noted that even Malevich's works were temporarily expelled from the public sphere when the Soviet authorities became unsympathetic towards radical artistic idealism. On the other hand, the non-realisation of Leko's project paradoxically refers directly to the distribution, relations, and the microphysics of power in the public sphere. In this way, this work actually also evokes Adorno's old thesis about the duality of modern art, it being at the same time an autonomous and a social fact, which will later, in the 1960s, be revived by the emergence of the New Avant-Garde (Fluxus, Happening, Neo-Dada, Neo-Constructivism, Neorealism, etc.) which transcended the limits of the highmodernist concept of the work of art and thus opened an autocritical debate on the sense of the aesthetic autonomy of art. This breakthrough moment in the development of $20^{\text {th }}$ century art practice, which also announced postmodern and contemporary art, was essentially marked by the change of the status of an artwork from the ontologicalmorphological into a critical-conceptual one. By asking the above questions about the functioning of the public sphere and the role and place of art in it, Leko's work uses art strategies derived from this new paradigm of artistic activity which, in the $21^{\text {st }}$ century, increasingly separates art, theory, media and everyday existential and social life. Such strategies and methods of work more often than not become the imperative of artistic activity in view of the complexity of contemporary society, and also bring to the fore 
artists as engaged intellectuals, which in some way perpetuates the modernist idea of changing the world through art. Despite the fact that it has never been realised in the physical space of Jelačić Square, this paper's focal by Kristina Leko mirrors the utopia of such an idea, but at the same time manages to convey its poetics to the audience by opening what the French custodian and theoretician of art Nicolas Bourriaud describes as an "alternative space".

\section{Alternative space}

In his famous work Relational Aesthetics, Nicolas Bourriaud seeks to answer the question: "What are the real challenges of contemporary art? What are its links with society, history, and culture?" (Bourriaud, 2013, 11). In order to understand the new art practices and the authors who appeared on the cultural scene in the 1990s, and in whose poetry he found certain common points with the new movement in art, Bourriaud suggests that it is necessary to proceed from the same situation as the artists, i.e. from the new political, cultural and social context of the information age, the expansion of the Internet and the globalised society. This change of "mental space" has given rise to a new way of thinking that has totally changed the features, statuses and functions of contemporary art, separating it from the previous period of postmodernism. Unlike similar artistic tendencies from earlier periods, aimed at extending the boundaries of art and exploring the relationships within the world of art, this newer art explores the relationships outside art, within the culture of eclecticism:

When Tiravanija offers us the experience of a structure in which he prepares food, he is not doing a performance: he is using the performance-form. His goal is not to question the limits of art: he uses forms that served to interrogate these limit sin the sixties, in order to produce completely different results. Tiravanija often cites Ludwig Wittgenstein's phrase: 'Don't look for the meaning, look for the use.' (Bourriaud, 2013, 146)

Referring to Debord and Marx, Bourriaud sees "relational" art as an interstice or interspace in a society of extras that followed the society of the spectacle, i.e., as a form of resistance or the possibility of functioning in another way:

These days, communications are plunging human contacts into monitored areas that divide the social bond up into (quite) different products. Artistic activity, for its part, strives to achieve modest connections, open up (one or two) obstructed passages, and connect levels of reality kept apart from one another. (Bourriaud, 2013, 12)

Art is thus a generator of behaviours and possible new uses of cultural codes, products on sale, ready-made forms, already built buildings, all forms of everyday life 
and all works of the world heritage, a generator which provokes such a "passive" culture contrasting it with products and their consumers (Bourriaud, 2013, 147). According to Bourriaud's definition, art is:

a general term describing a set of objects presented as part of a narrative known as art history. This narrative draws up the critical genealogy and discusses the issues raised by these objects, by way of three sub-sets: painting, sculpture, architecture. Nowadays, the word "art" seems to be no more than a semantic leftover of this narrative, whose more accurate definition would read as follows: Art is an activity consisting in producing relationships with the world with the help of signs, forms, actions and objects. (Bourriaud, 2013, 137)

The artistic object of relational art is no longer defined materially or conceptually, but relationally. The meaning of the work thus arises from the characteristics set by the artist, but also from the cooperation of other visitors throughout the duration of the exhibition, whereby the meaning develops collectively, not within the space of individual consumption (Arnautović, 2009, 744). By entering an artwork into a network of signs and meanings, rather than considering it an autonomous and distinct form, it is possible to create a new cartography of knowledge, an invention of the original paths through culture.

Closely following the work of a number of artists appearing in the 1990s, Bourriaud found some common features in their various poetics and called them postmodern. In connection with this, he constructed three new terms that, as well as the concepts they denote, soon found their application in the world of culture and art: "relational aesthetics", "postproduction" and "altermodern". All three concepts are interlinked and derived from the peculiarities of new, relational, postproduction and altermodern art. These terms reflect new approaches to often unreadable specific art practices with which Bourriaud conceives contemporary art. His "relational aesthetics" is an example of interpretative strategy as an interactive and intertextual reading which, unlike traditional aesthetics, is not concerned with the cognisance of autonomous, beautiful or autonomous art, but rather considers the functional relationship between art and culture and its mechanisms of constituting plural and fragmentary fields of social relations and an exchange of meaning.

Such an interpretative strategy stems from the analysis of the relationship between the position of the subject actuator and the position of the subject of consumption, which actually enables communication and exchange of art, and it is precisely in the concept of relationship or relation that it defines new features, statuses and functions of the so-called "relational" art. Relational art thus seeks to create an alternative to the 
market space imposed by the modern global capitalist society, which also determines the so-called "information highways" and shapes social relationships into a variety of standardised and bureaucratised models where the individual is reduced to a mere consumer of space and time. The alternative space that is the aim of relational art as a way of functioning in a different way is an interstice or a form of resistance to the hegemony of the society of the spectacle, which makes it at least partially protected from the uniform social behaviour:

No public image should benefit from impunity, for whatever reason: a logo belongs to public space, since it exists in the streets and appears on the objects we use. A legal battle is underway that places artists at the forefront: no sign must remain inert, no image must remain untouchable. Art represents a counterpower. Not that the task of artists consists in denouncing, mobilizing, or protesting: all art is engaged, whatever its nature and its goals. Today there is a quarrel over representation that sets art and the official image of reality against each other; it is propagated by advertising discourse, relayed by the media, organized by an ultralight ideology of consumption and social competition. In our daily lives, we come across fictions, representations, and forms that sustain this collective imaginary whose contents are dictated by power. Art puts us in the presence of counterimages, forms that question social forms. In the face of economic abstraction that makes daily life unreal, or an absolute weapon of techno-market power, artists reactivate forms by inhabiting them, pirating private property and copyrights, brands and products, museum-bound forms and signatures. (Bourriaud, 2013, 230)

In his explanation of the alternative space, this author sees the historical task of the early $21^{\text {st }}$ century as the rewriting of modernity, in which modernity is a "taste for aesthetic experience and adventurous thinking" that is not dead, but is only losing its teleological and idealistic vision and the need for the "always new". According to Bourriaud, in modern art, modernity continues its existence by micro-remodelling and recycling the factual situation in culture, "inventing" everyday life and redesigning empirical time and space. While "the first" modernism was based on conflict and opposition, "the second" modernism (modernism after modernism) should progress by discovering new connections and possible relations. Unlike militant avant-garde movements, it does not seek to create some imagined or optimal reality, but rather to establish the forms of existence and patterns of action within the existing reality.

Kristina Leko's artistic practice is mainly directed towards social interaction in the public space, and she affirms through each of her projects the faith in the effectiveness of artistic engagement based on "the responsibility for the image of the world" (Janković, 2005, 24), as witnessed by her latest large-scale exhibition How 
People Live - a Report on Passivity that was on display at the Zagreb Museum of Contemporary Art (2016). In Leko's words,

No matter how dramatic the changes may seem, if we look at art over a long historical period and in the new technological environment, the fundamental feature of a work of art is still for it to exist for its own sake. If we say that art is communication or the process of communication, then it is communication for the sake of communication: without premeditation, for the purpose of contact without interest, for the purpose of getting to know the other. More than ever, it is clear that no technological novelty alone can guarantee progress. It is restructuring interpersonal relationships and improving communications that the use of these novelties provides. This is the line of thought along which the recent, new art, using technology, currently emphasises itself as a very much alive and referential social sphere. In this, of course, it does not matter how much it really is that, but how much it really wants to be it. (Leko, 1999, 13)

\section{The form of a work}

Viewed from the traditional perspective, the form in contemporary art, whether composed of processes or procedures, is "broken". However, if we consider the form as an essential determinant of fine and/or visual arts, we are bound to agree with Pierre Francastel (Francastel, 2006, 55), who uses for them the term plastic arts, and claims that all plastic arts are arts of space, that there is no plastic art outside space, and that human thought, when expressed in space, necessarily acquires a plastic form. At the same time, the term "form" is applied to the general interpretation of the activity of the spirit (which can be musical, literary or mathematical, just as much as plastic). The articulation and realisation of a work in the social and culturological space largely determines contemporary artistic practice, or at least that part of it that conceptually invokes the social dimension of its artefacts (artistic work as a social fact), and has its roots in the historical avant-garde and later neo-avant-gardes all the way up to neoconceptualism and the dominance of the mass media in postmodernist culture. In line with these observations, Leko's work reviews, in a highly intriguing and intelligent way, the experience of space through its poetic transformation from a physical, through metaphysical to a political phenomenon and their interrelationship. Therefore, the form of her work presents itself as elusive, fluctuating and interactive, and seems closest to what Bourriaud calls "relational form".

The relational form can be read as a conceptual determinant of contemporary art practice which, under the term of interactive art, brings together socially engaged, activist or dialogue arts, participatory arts, public arts of the new genre (New Genre 
Public Art), which the art and architecture critic Miwon Kwon defines as the third phase in the change of paradigm of art in public spaces over the past decades: art in public spaces, typically modernist abstract sculptures in an external space intended to "beautify" or "enrich" the urban space, through the concept of art in public spaces that seeks a more intensive integration of art, architecture and surroundings, for which artists work together on permanent projects with those responsible for designing the town, to the so-called art in the public interest which is more concerned with social themes than with the surroundings, and which favours cooperation with social groups over that with professionals, and which makes use of participation methods to include people in the creative process, thus trying to raise social political awareness:

These three paradigms of public art reflect broader shifts in advanced art practices over the past thirty years: the slide of emphasis from aesthetic concerns to social issues, from the conception of an art work primarily as an object to ephemeral processes or events, from the prevalence of permanent installations to temporary interventions, from the primacy of production as source of meaning to reception as site of interpretation, and from autonomy of authorship to its multiplicitous expansion in participatory collaborations. $\left(\right.$ Kwon, 2017) ${ }^{3}$

Since art in public spaces, as a culture of memory or representation of power, can be considered to be one of the oldest artistic forms, interactive art in the public sphere differs from the latter by the participation and interaction of people by means of the artistic process or product by which it challenges the issues of legacy, meaning and power in the public sphere (Bosch, 2011, 67). In this way artists do succeed in "moving" something. Leko's socially engaged art project Cheese and Cream, in which she tried to help Zagreb's dairymaids by organizing some happenings in which she criticised cheap production and rejection of the country's own traditions, actually managed to have an impact on official politics.

Although, regrettably, we have not been able to see Leko's work as it was conceived in the public space of the square, it clearly demonstrates the way in which the original meaning of a public space is lost through the domination of values or ideologies in the late capitalist era. The "invisibility" of the form of this work paradoxically makes "visible" the original meaning by problematising relations in public spaces and challenging its public nature. The form of work is thus constructed by different spaces of observation and means of communication, different from the ones imposed as the only possible options. The work is still topical and works through its own persuasiveness, its form being a kind of "work in progress" which sensitises and expands the public space, an "open work" or a form of knowledge of the world we live in:

3 Miwon Kwon: Public Art and Urban Identities, http://eipcp.net/transversal/0102/kwon [1. 2. 2017]. 
the poetics of the "open" work tends to encourage "acts of conscious freedom" on part of the performer and place him at the focal point of a network of limitless interrelations, among which he chooses to set up his own form without being influenced by an external necessity which definitively prescribes the organisation of the work in hand. At this point, one could object (with reference to the wider meaning of "openness" already introduced in this essay) that any work of art, even if it is not passed on to the addressee in an unfinished state, demands a free, inventive response, if only because it cannot really be appreciated unless the performer somehow reinvents it in psychological collaboration with the author himself. Yet this remark represents the theoretical perception of contemporary aesthetics, achieved only after painstaking consideration of the function of artistic performance; certainly an artist of a few centuries ago was far from being aware of these issues. Instead, nowadays it is primarily the artist who is aware of its implications. In fact, rather than submit to the "openness" as an inescapable element of artistic interpretation, he subsumes it into a positive aspect of his production, recasting the work so as to expose it to the maximum possible "opening". (Eco, $1965,35)$

On the other hand, the meaning potentiality of Leko's work may primarily be reminiscent of the form of a rhizome (Deleuze and Guattari): "it is a question of a model that is perpetually in construction or collapsing, and of a process that is perpetually prolonging itself, breaking off and starting up again" (Deleuze, Guattari, 2013, 29), that would "ceaselessly establish connections between semiotic chains, organisations of power, and circumstances relative to the arts, sciences, and social struggles" (Deleuze, Guattari, 2013, 14). A rhizome is a map that "uses very different regimes of sign and even non-sign states" (Deleuze, Guattari, 2013, 29), which "has no beginning or end, is always in the middle, between things, interbeing, intermezzo" (Deleuze, Guattari, 2013,34). Namely, the work maps both the existing semiotic chains (advertisements on the square) and those which contrast them (Malevich's suprematism, non-realisation of the work in a public space), through which it actually enables and establishes its own duration and spatialisation:

The rhizome operates by variation, expansion, conquest, capture, offshoots. Unlike the graphic arts, drawing, or photography, unlike tracings, the rhizome pertains to a map that must be produced, constructed, a map that is always detachable, connectable, reversible, modifiable, and has multiple entry ways and exits and its own lines off light. It is tracings that must be put on the map, not the opposite. In contrast to centred (even polycentric) systems with hierarchical modes of communication and preestablished paths, the rhizome 
is anacentred, non-hierarchical, nonsignifying system without a general and without an organising memory or central automaton, defined solely by a circulation of states." (Deleuze, Guattari, 2013, 30)

\section{Conclusion}

The initial goal has been achieved: although, or perhaps indeed because it has not been realised in the square, Leko's intervention offers "what we cannot achieve in real life, namely, a peaceful contemplation of metaphysical values" (Roman Ingarden). Hence the work of Suprematism on the Square convincingly demonstrates the end of a utopia of the modernist idea of changing the world by means of art, and yet it does not give up: it seeks to win the space of autonomy by a qualitative change in individual perceptions, restructuring and profiling of interpersonal relationships, polemicising and producing antagonism. The stratification of the composition therefore manifests itself as an aesthetic experience - the experience of the space made to the human scale.

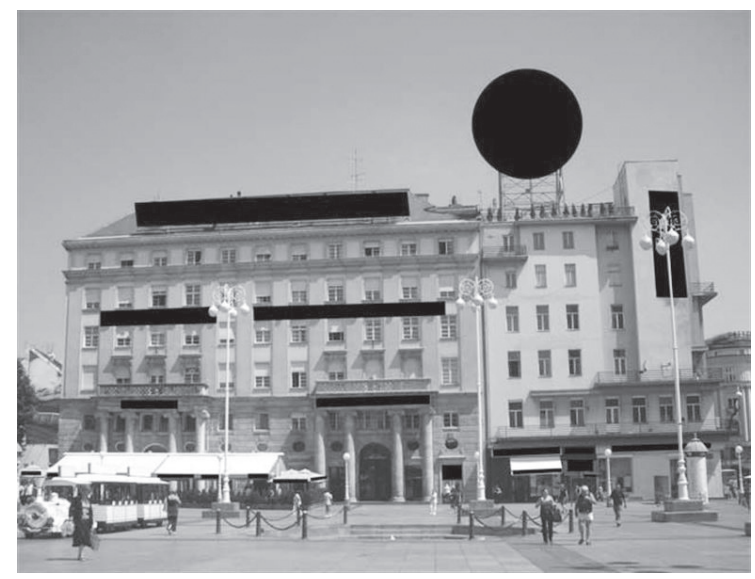

Picture 1: Suprematist Composition No. 1, Black on Grey, https://www.slobodnadalmacija.hr/scena/kultura/clanak/id/32029/korporacijeprotiv-umjetničke-akcije.

\section{References}

Arnautović, J., Nikola Burio, in: Figure u pokretu. Suvremena zapadna estetika, filozofija i teorija umetnosti (ed. Šuvaković, M., Erjavec, A.), Beograd 2009.

Bosch, S., Razmišljanja o mogućnosti podučavanja participacijske umjetnosti u javnom prostoru, in: Život umjetnosti, 88, 2011, pp. 66-77. 
Bourriaud, N., Relacijska estetika, Zagreb 2013.

Briski-Uzelac, S., Vizualni tekst. Studije iz teorije umjetnosti, Zagreb 2008.

Deleuze, G., Guattari F., Kapitalizam i šizofrenija 2. Tisuću platoa, Zagreb 2013.

De Micheli, M., Umjetničke avangarde XX. stoljeća, Zagreb 1990.

Eco, U., Otvoreno djelo, Sarajevo, 1965.

Francastel, P., Genetički i plastički prostor, in: Život umjetnosti, 78/79, 2006, pp. 55-65.

Greenberg, C., Modernist Painting, in: Art in Theory 1900-2000: An Anthology of Changing Ideas, (ed. Harrison, Ch., Wood, P.), USA 1992.

Janković, I. R., Odgovornost za sliku svijeta - razgovor sa Kristinom Leko, in: Život umjetnosti, 74/75, 2005, pp. 24-43.

Kwon, M., Public Art and Urban Identities, http://eipcp.net/transversal/0102/kwon [1. 2. 2017].

Leko, K., Umjetnost, društvo, medijski i javni prostor, in: Život umjetnosti, 61/62, 1999, pp. $12-15$.

Leko, K., Suprematistička kompozicija br. 1, Crno na sivom, 2008, in: Operacija grad. Priručnik za život u neoliberalnoj stvarnosti (ed. Domes, T.), Zagreb 2008, pp. 238-240.

Maljevič, K., Suprematizam, in: Umjetničke avangarde XX. stoljeća (ed. De Micheli, M.), Zagreb 1990, pp. 252-259.

Pažin, V., Korporacije protiv umjetničke akcije, Slobodna Dalmacija, 7. 12. 2008. www.slobodnadalmacija.hr/scena/kultura/clanak/id/32029/korporacije-protivumjetnicke-akcije [1. 2. 2017].

Schmidt-Wulffen, S. (ed.), The Artist as Public Intelectual, Vienna 2008. 


\section{Katarina Rukavina}

\section{Poetična razstava izkušnje prostora: Suprematistična kompozicija št. 1, Črno na sivem Kristine Leko}

Ključne besede: alternativni prostor, interaktivna umetnost, relacijska forma, suprematizem na trgu

Članek analizira koncept prostora $\mathrm{v}$ sodobni umetnosti na primeru dela Suprematistična kompozicija št. 1, Črno na sivem umetnice Kristine Leko iz leta 2008. Opirajoč se na Malevičev suprematizem je K. Leko decembra 2008 pričela s projektom umetniške intervencije na Trgu bana Jelačića v Zagrebu, kjer je nameravala s črno pokriti vse reklame, oglase, znake in imena tovarn. Cilj poetične intervencije, kot jo imenuje umetnica, je bil ozavestiti ljudi o relativiziranju materialnih dobrin v predbožičnem času. Kljub pridobljenim dovoljenjem mestnih oblasti so vpletene tovarne zavrnile sodelovanje, pa čeprav le za 24 ur, zato projekt nikoli ni bil realiziran. Kljub temu delo obstaja $\mathrm{v}$ virtualnem prostoru, ki je ravno tako javen, ter nadaljuje delovanje $\mathrm{v}$ obliki dokumentacije. Ravno neizvedenost intervencije oziroma nevidljivost dela na Jelačićevem trgu ga dela vidljivega, usmerjeno kaže na urejenost moči in konstrukcijo vrednosti v družbi ter odpira nova vprašanja. Delo tako vendarle prihaja v javni prostor ter ga senzibilizira in razširja. 
Katarina Rukavina

\section{Poetic Examination of Spatial Experience: Suprematist Composition No. 1, Black on Grey by Kristina Leko}

Keywords: alternative space, interactive art, relational form, suprematism on square

The paper analyses the concept of space in contemporary art on the example of Suprematist Composition No. 1, Black on Grey by Kristina Leko from 2008. Referring to Malevich's suprematism, in December 2008 Leko initiated a project of art intervention in Ban Jelačić Square in Zagreb, where she intended to cover in black all commercials, advertisements, signs and names of various companies. This poetic intervention, as the artist calls it, was intended to prompt people to relativise material goods in the pre-Christmas period. However, despite the authorisation obtained from the city authorities, the companies concerned refused to remove their respective advertisements, be it for only for 24 hours, so this project has never been realised. The project, however, does exist in the virtual space, which is also public, and continues to act in the form of documentation. The non-feasibility of the intervention, or rather its invisibility on Jelačić Square, makes visible or directly indicates the ordering of the powers and the constellation of values in the social sphere, thus raising new questions. Indeed, in this way it actually enters the public space, sensitising and expanding it at the same time. 